\title{
PERCEIVED BARRIERS TO LEISURE-TIME PHYSICAL ACTIVITY IN THE BRAZILIAN POPULATION
}

BARREIRAS PERCEBIDAS PARA A PRÁTICA DE ATIVIDADE FÍSICA NO LAZER DA POPULAÇÃO BRASILEIRA

PERCEPCIÓN DE BARRERAS A LA ACTIVIDAD FÍSICA DURANTE EL TIEMPO LIBRE EN LA

POBLACION BRASILENA
Cassiano Ricardo Rech'

(Physical Education Professional)

Edina Maria de Camargo²

(Physical Education Professional)

Pablo Antonio Bertasso de Araujo ${ }^{3}$ (Physical Education Professional)

Mathias Roberto Loch $^{4}$

(Physical Education Professional)

Rodrigo Siqueira Reis 5,6

(Physical Education Professional)

1. Universidade Federal de

Santa Catarina, Program of Post-

Graduation in Physical Education,

Florianópolis, SC, Brazil.

2. Universidade Federal do Paraná,

Program of Post- Graduation in

Physical Education, Centro de

Estudos em Atividade Física e

Saúde (CEAFS), Curitiba, PR, Brazil.

3. Universidade do Estado de

Santa Catarina, Multiprofessional

Residency in Family Health,

Florianópolis, SC, Brazil.

4. Universidade Estadual de

Londrina, Program of Post-

Graduation Education in Collective

Health, Londrina, PR, Brazil.

5. Washington University in St. Louis Brown School, Prevention Research Center, Saint Louis, MO,

United States.

6. Pontifícia Universidade Católica do Paraná, Program of Post-

Graduation in Urban Management, Grupo de Pesquisa em Atividade

Física e Qualidade de Vida (GPAQ), Curitiba-PR, Brazil.

\section{Correspondence:}

Campus Universitário Reitor João David F Lima, Prédio Administrativo Centro de Desportos, 200. Trindade, Florianópolis, Santa Catarina, Brazil. 88040-9000. crrech@hotmail.com

\begin{abstract}
The aim of this study was to synthesize and analyze scientific evidence of the perceived barriers to leisure-time physical activity (PA) in the Brazilian population. The Lilacs, SciELO, PubMed, ScienceDirect and Web of Science journal databases were reviewed and the number of reports of each barrier to PA, grouped according to the level of determinants of the social ecological model (intrapersonal, interpersonal and environmental) was analyzed. We found 25 studies (11 in adolescents, 8 in adults and 6 in older adults), totaling 62,678 reports of barriers to PA. The studies were conducted in the South $(n=15)$, Southeast $(n=7)$, and Northeast $(n=2)$ regions, and one study also included different regions of Brazil. Overall, about seven out of every 10 reports on barriers to PA involved intrapersonal barriers. Adults and older adults had a higher proportion of reports of intrapersonal barriers (84.8\% and $74 \%$, respectively), than adolescents (47.8\%). There are still few studies with older adults, children, and in populations of the Midwest and North of the country. The most frequently reported barriers to PA among adolescents were lack of company, lack of social support from family and friends, unsuitable climate and limited access to spaces for PA. Lack of motivation and lack of time were the most frequently reported barriers in adults, whereas in older adults the predominant barriers were lack of motivation and diagnosed disease or physical limitation. PA promotion programs need to take into account the different barriers to PA, since these are specific to age groups. Level of Evidence Il; Systematic Review of Level II Studies.
\end{abstract}

Keywords: Physical activity; Physical exercise; Population; Health promotion.

\section{RESUMO}

Este estudo teve como objetivo sintetizar e analisar evidências cientificas sobre as barreiras percebidas para atividade física (AF) no lazer da população brasileira. Foram revisadas as bases de periódicos Lilacs, SciELO, PubMed, Science Directe Web of Science e analisados o número de relatos de cada barreira para AF, agrupada de acordo com o nivel de determinantes do modelo socioecológico (intrapessoal, interpessoal e ambiental). Foram encontrados 25 estudos (11 em adolescentes, oito em adultos e seis em idosos), totalizando 62.678 relatos de barreiras para AF. Os estudos foram conduzidos nas regiões Sul ( $n=15)$, Sudeste $(n=7)$, Nordeste ( $n=2)$ e um estudo ainda incluiu diferentes regiões do Brasil. No geral, cerca de sete em cada 10 relatos de barreiras para AF foram relacionadas com o nivel intrapessoal. Adultos e idosos apresentaram maior proporção de relatos intrapessoais (84,8\% e 74,0\%; respectivamente), quando comparado com adolescente (47,8\%). Ainda são escassos estudos com idosos, crianças e nas populações das regiões Centro-Oeste e Norte do País. As barreiras para AF mais reportadas entre os adolescentes foram falta de companhia, falta de apoio social da família e amigos, clima inadequado e baixo acesso a locais para AF. Em adultos a falta de motivação e a falta de tempo foram as barreiras com maior relato e, em idosos, a falta de motivação e diagnóstico de doença ou limitação física. Programas de promoção de AF necessitam levar em conta as diferentes barreiras para a AF, pois essas se mostram específicas aos grupos etários. Nível de Evidência Il; Revisão Sistemática de Estudos de Nível II.

Descritores: Atividade física; Exercício físico; População; Promoção da saúde.

\section{RESUMEN}

Este estudio tuvo por objetivo resumiry analizar la evidencia científica sobre las barreras percibidas para la actividad física (AF) en el tiempo libre de la población brasileña. Las bases que se revisaron fueron Lilacs, SciELO, PubMed, Science Direct y Web of Science y se analizó el número de informes de cada barrera a la FA agrupados de acuerdo al nivel de los determinantes del modelo socio-ecológico (intrapersonal, interpersonal y ambientales). Se encontraron 25 estudios (11 en adolescentes, 8 en adultos y 6 en ancianos), de un total de 62.678 informes de barreras a la AF. Los estudios se realizaron en el Sur $(n=15)$, Sureste $(n=7)$, Noreste $(n=2)$ y una medida incluye diferentes regiones de Brasil. En general, aproximadamente siete de cada 10 que informaron las barreras a la AF estaban relacionados con el nivel intrapersonal. Adultos y ancianos presentaron mayor proporción de informes intrapersonales (84,8\% y 74,0\%, respectivamente) en comparación con los adolescentes (47,8\%), aunque hay pocos estudios con personas mayores, niños y poblaciones de la región central y norte del país. Las barreras a la AF más reportadas entre los adolescentes fueron la falta de compañía, la falta de apoyo social de amigos y familiares, mal tiempo y bajo acceso a lugares de AF. 
En adultos, la falta de motivación y falta de tiempo fueron las barreras para una mayor consideración, yen ancianos, la falta de motivación y diagnóstico de enfermedad física o limitación. Programas de promoción de AF deben tener en cuenta las diferentes barreras a la AF, ya que estos se muestran a grupos de edad específicos. Nivel de Evidencia Il; Revision Sistemática de estudios de nivel II.

Descriptores: Actividad física; Ejercicio físico; Población; Promoción de salud.

\section{INTRODUCTION}

An important aspect for the success of individual or community-based programs and interventions promoting physical activity (PA) is the identification of factors that limit the participation and continuation in these programs ${ }^{1,2}$. Within this context, a critical analysis of perceived barriers to PA may be useful to develop appropriate sociocultural and environmental approaches aimed at promoting a more physically active lifestyle $e^{1,2}$.

Systematic reviews have demonstrated an inverse relationship between the perception and number of barriers and levels of $\mathrm{PA}^{3,4}$. Furthermore, the perceived barriers to PA can vary between age groups and according to the context of people's lives ${ }^{5}$, as demonstrated in several cross-sectional studies on adolescents ${ }^{6,7}$, adults ${ }^{8,9}$, and older adults ${ }^{10,11}$. These differences may be explained, at least in part, by social, cultural and environmental characteristics such as norms and local culture ${ }^{12,13}$. Differences between age groups and genders may occur in the frequency of reported barriers, as well as in the domains or type of PA barriers. For example, socioecological models consider that multiple factors can influence PA, including intrapersonal, interpersonal and environmental variables ${ }^{2,14}$. In this respect, there was high economic and social inequality in Brazil, and important variability may exist in the distribution of PA barriers across the domains of the socioecological model. It is therefore important to know the barriers to PA in different groups and contexts.

Considering the great territorial extension of Brazil and its cultural and economic diversity, one can expect important differences in perceptions between men and women and between different age groups. In this regard, knowledge of the barriers to PA in the Brazilian population is fundamental to develop PA promotion strategies in the country ${ }^{15}$. Therefore, the aim of this study was to synthesize and analyze the available evidence on perceived barriers to PA in the Brazilian population.

\section{METHODS}

\section{Search strategy}

This systematic review followed the standard procedures described in the literature ${ }^{16}$. We systematically reviewed articles published in peer-reviewed journals indexed in the Lilacs, SciELO, PubMed, Science Direct, and Web of Science electronic journal databases. Qualitative and quantitative studies reporting the results of barriers to PA (prevalence and/or reports), which involved samples of the Brazilian population and were published in Portuguese or English, were included. The search was limited to articles published between January 2000 and September 2016.

Reviews, opinions, letters to the editor, books, book chapters, research reports, dissertations, and theses were excluded from the analysis. Studies on PA barriers that only included population samples with special conditions or investigated in clinical studies (e.g., individuals with heart disease, HIV, and cancer) were also excluded. Search terms/keywords related to PA and barriers to PA were used and only studies involving samples of the Brazilian population (Brazil, Brazilians) were included. The search terms were combined using the Boolean operators "AND" and "OR". The following syntax and search terms were used: ("motor activity" OR "locomotor activity" OR "physical activity" OR exercise OR sports OR walking) AND (barriers OR "perceived barriers" OR facilitators OR adherence OR adhesion OR abandonment) AND (Brazil OR Brazilian). The search terms were selected from the Medical Subject Headings (MeSH), Descriptors of Health Sciences (DeCS), and scientific articles on the topic.

\section{Selection of studies and extraction of information}

The PRISMA Statement ${ }^{16}$ was used for selection of the studies. The search comprised three stages, reading the titles, abstracts and full texts, which were performed independently by two researchers. A third opinion was obtained in the case of divergence. After selection of the articles, the following information was extracted: author, year of publication, place of study, age range, size and sex of the sample, sample selection method, study design, type of study, data collection method, and instrument used to measure barriers to PA. The information was also extracted independently by two researchers.

\section{Analysis of studies}

Since the barriers to PA reported can vary according to individual characteristics, the analysis was stratified by age group (children and adolescents, adults, and older adults) and sex (female and male) according to the categories of PA determinants in the socioecological model ${ }^{2,17}$. In this model, the determinants of PA are divided into intrapersonal (psychological: cognitive aspects, beliefs, motivation; biological: sex, age, genetic factors, health conditions), interpersonal (social support from family and friends, social and cultural norms), environmental (social, built, and natural environment), and organizational level (transport system, media, local policies, economic aspects of the country) 2,5,17. This classification was based on evidence indicating multiple levels of influence on a behavior ${ }^{2,17}$.

Quantitative studies (those using questionnaires or standardized scales to identify the number of barriers for each age group) and mixed qualitative-quantitative studies (those using content analysis, focus groups, and semi-structured interviews as a method for data collection and analysis) were included. For the analysis of quantitative studies, the absolute number of individuals that reported each barrier was considered the unit of analysis.

Finally, the selected articles were evaluated regarding the quality of internal validity and criteria to establish causality using an adapted scale $^{18}$. Among the 27 original items, only 16 were used for analysis because they were related to observational (cross-sectional) studies. The following items were evaluated: quality of description of the hypotheses/objectives; quality of description of the outcome to be measured; characterization of the sample; quality of description of the exposures of interest; discussion of the main confounding factors; providing estimates of random variability for the main findings; reporting the actual probability found; selection and inclusion of representative samples; analysis of the main results; adequacy of the statistical tests used to measure the main outcomes; exposures without classification errors; accuracy of the instruments used for the main outcomes; adequate adjustment for the main confounding factors; adequacy of the statistical power to detect a significant effect at a significance level of $5 \%$. The score of the scale ranges from 0 (worst) to 17 (best) (one of the items has weight 2). The absolute quality index was defined as the sum of items and the relative quality index as the ratio of the sum of items divided by the total number of items in the scale. 


\section{RESULTS}

\section{Systematic search results}

The initial search identified 1,407 titles (118 duplicates). After reading the remaining titles $(1,289=100 \%), 1,161(90.9 \%)$ were excluded since they were not related to the subject. Next, the abstracts were read and 105 (9.1\%) articles were excluded because they did not include barriers to PA. Finally, 23 papers (1.9\%) were selected for reading the full text. Seven new studies were identified in the reference lists of these articles and included. After reading, five articles were excluded because they did not contain barriers to PA. Twenty-five (2.1\%) studies published between 2004 and 2016 were thus included (Figure 1).

\section{Characteristics of the studies}

The studies included the reports of 62,678 subjects aged 10 to 90 years. The sample size ranged from 25 to 46,981 participants. Most studies were conducted in the Southern $(n=15)$, Southeastern $(n=7)$ and Northeastern $(n=2)$ regions and one study comprised different regions of Brazil. No studies conducted in the Midwest or Northern region of the country were identified. There was a larger number of studies involving adolescents $(n=11)$, followed by adults $(n=8)$ and older adults $(n=6)$. The method of data collection were questionnaires/scales in most studies $(n=21)$ and only four used focus groups. Regarding the quality of the studies, about half the articles (56.0\%) met at least $70.0 \%$ of the criteria used. Further information about the characteristics of the studies is given in Table 1.

The studies involving adolescents $(n=11)$ were published between 2004 and 2015, with 8,350 participants aged 10 to 19 years. A total of 23,005 reports comprising 23 different types of barriers to PA were included. Nine studies involving adults (20-65 years) published between 2006 and 2016 were identified. Most of these studies were conducted in the Southern region $(n=6)$, one study was conducted in the Northeastern region, and one involved a sample from the capitals of Brazil. The studies included 53,637 adults and reported 15 barriers to PA. For the elderly population, six studies were published between 2008 and 2016, which investigated 691 older adults (60-90 years). Three of these studies were conducted in the Southeastern region. Questionnaires were the main method of data collection $(n=4)$, followed by focus groups $(n=2)$ Overall, 15 barriers to PA were reported in these studies (Table 1).

\section{Perceived barriers to physical activity according to socioe- cological determinant}

Figure 2 shows the barriers to PA according to the determinants of PA in the socioecological model and age group. In general, most reports are classified as intrapersonal (68.9\%) in all age groups, followed by environmental (17.5\%) and interpersonal (13.6\%).

With respect to age group, the proportion of intrapersonal barriers was higher among adults and older adults ( $84.8 \%$ and $74.0 \%$, respectively) when compared to adolescents (47.8\%). On the other hand, adolescents reported a higher proportion of interpersonal (28.1\%) and environmental (24.1\%) barriers than adults and older adults (adults: 5.1\% and 10.1\%; older adults: $7.8 \%$ and, $18.2 \%$, respectively) (Figure 2). Finally, we found no studies analyzing barriers related to global or organizational determinants.

Analysis of the reports according to sex (Figure 3) showed a similar sex distribution of barriers at each level of the socioecological model in adolescents and older adults. However, in adults, the proportion of intrapersonal barriers was higher among women compared to men $(92.1 \%$ versus $81.7 \%, \mathrm{p}<0.05)$, while the proportion of PA barriers at the environmental level was higher among adult men compared to women $(12.7 \%$ versus $4.8 \%, p<0.05)$.

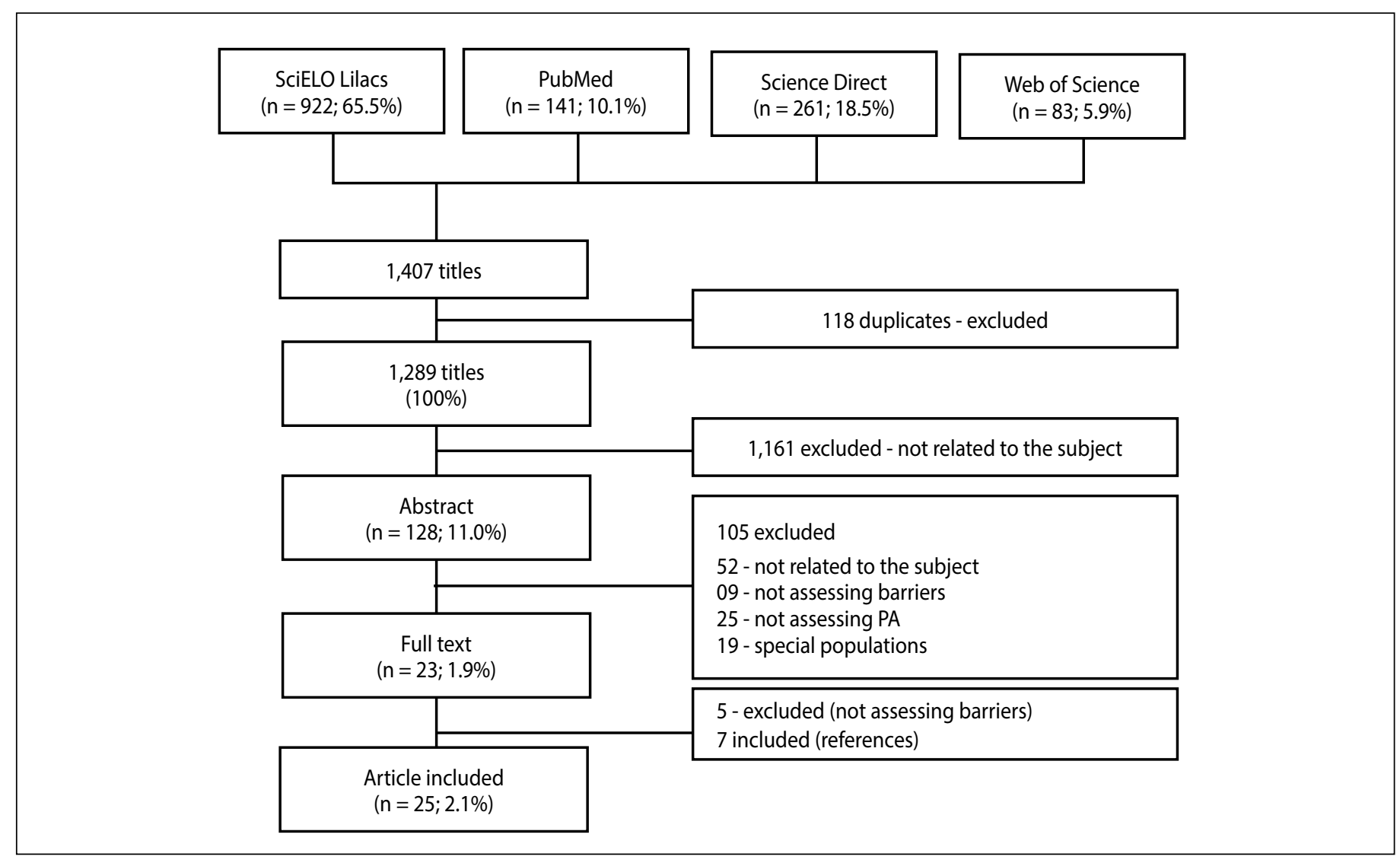

Figure 1. Flow chart showing selection of the articles included in the systematic review on barriers to physical activity in the Brazilian population (2016). PA, physical activity. 
Table 1. Characteristics of the studies included in the systematic review on barriers to physical activity in the Brazilian population. 2016. ( $\mathrm{n}=25$ ).

\begin{tabular}{|c|c|c|c|c|c|c|c|c|c|c|c|c|c|}
\hline Group & Author & Year & City & State & $\mathrm{n}$ & $\begin{array}{c}\text { Age } \\
\text { (years) }\end{array}$ & Sex & $\begin{array}{c}\text { Sample } \\
\text { selection }\end{array}$ & Type of study & $\begin{array}{c}\text { Collection } \\
\text { method }\end{array}$ & Instrument & \begin{tabular}{|l|} 
Quality \\
of study
\end{tabular} & $\%{ }^{b}$ \\
\hline \multirow{11}{*}{ Adolescents } & Teixeira et al. ${ }^{19}$ & 2004 & São Caetano Sul & SP & 101 & $M=14$ & $M, F$ & $\mathrm{NI}$ & Quantitative & Questionnaire & $\mathrm{NI}$ & 6 & 37.5 \\
\hline & Ceschini et al. ${ }^{20}$ & 2007 & São Paulo & SP & 1,738 & $15-17$ & $M, F$ & Intentional & Quantitative & Questionnaire & Questionnaire & 6 & 37.5 \\
\hline & $\begin{array}{l}\text { Figueira Jr } \\
\text { et al. }{ }^{21}\end{array}$ & 2009 & São Paulod & SP & 198 & $14-17$ & $M, F$ & Intentional & Quantitative & Questionnaire & Questionnaire & 9 & 56.2 \\
\hline & Santos et al. ${ }^{22}$ & 2009 & Curitiba & PR & 59 & $15-18$ & $M, F$ & Intentional & Qualitative & Focus group & Focus group & 13 & 81.3 \\
\hline & Santos et al. ${ }^{7}$ & 2010 & Curitiba & $P R$ & 1,609 & 14-18 & $M, F$ & Random & Quantitative & Questionnaire & Santos et al. & 15 & 93.8 \\
\hline & Copetti et al. ${ }^{23}$ & 2010 & Pelotas & RS & 399 & $10-19$ & $M, F$ & Random & Quantitative & Questionnaire & Reichert et al. & 9 & 56.2 \\
\hline & Silva et al. ${ }^{24}$ & 2010 & Simão Dias & SE & 281 & $15-19$ & $M, F$ & Random & Quantitative & Questionnaire & Question & 12 & 75.0 \\
\hline & Dambros et al. ${ }^{6}$ & 2011 & Santa Maria & RS & 424 & 14-18 & $M, F$ & Random & Quantitative & Questionnaire & Martins et al. & 10 & 62.5 \\
\hline & Silva et al. ${ }^{25}$ & 2011 & Caxias do Sul & RS & 1,622 & $11-17$ & $M, F$ & Random & Quantitative & Questionnaire & CDC & 14 & 87.5 \\
\hline & Muller e Silva ${ }^{26}$ & 2013 & Cidades do Sulc & RS & 510 & $13-19$ & $M, F$ & Intentional & Quantitative & Questionnaire & Reichert et al. & 16 & 94.1 \\
\hline & Dias et al. ${ }^{27}$ & 2015 & Londrina & PR & 1,409 & 14-19 & $M, F$ & Random & Quantitative & Questionnaire & Santos et al. & 15 & 93.7 \\
\hline \multirow{8}{*}{ Adults } & Reichert et al. ${ }^{28}$ & 2006 & Pelotas & $\mathrm{RS}$ & 3,100 & $>20$ & $M, F$ & Random & Quantitative & Questionnaire & Reichert et al. & 15 & 93.8 \\
\hline & Silva et al. ${ }^{29}$ & 2009 & Curitiba & PR & 721 & $\geq 18$ & $M, F$ & Intentional & Quantitative & Questionnaire & Reis et al. & 13 & 81.3 \\
\hline & Silva et al. ${ }^{23}$ & 2011 & $\mathrm{RS}$ & $\mathrm{RS}$ & 2,265 & $30-50$ & $M, F$ & Random & Quantitative & Questionnaire & Question & 14 & 87.5 \\
\hline & $\begin{array}{c}\text { Nogueira e } \\
\text { Sousa }^{30}\end{array}$ & 2012 & Santa Maria & $\mathrm{RS}$ & 53 & $30-47$ & $M, F$ & Intentional & Quantitative & Questionnaire & Petroski et al. & 10 & 62.5 \\
\hline & Rigoni et al. ${ }^{31}$ & 2012 & Maringá & PR & 153 & $21( \pm 3)$ & $M, F$ & Intentional & Quantitative & Questionnaire & Petroski et al. & 13 & 81.2 \\
\hline & Jesus et al. ${ }^{32}$ & 2012 & Feira de Santana & $\mathrm{BA}$ & 316 & $>30$ & $M, F$ & Intentional & Quantitative & Questionnaire & Martins et al. & 10 & 62.5 \\
\hline & Camargo et al. ${ }^{9}$ & 2014 & Curitiba & $P R$ & 48 & $18-65$ & $M, F$ & Intentional & Qualitative & Focus group & Focus group & 12 & 75.0 \\
\hline & Silva et al. ${ }^{33}$ & 2016 & Brazilian capitals & $\mathrm{BR}$ & 46,981 & $18-\geq 50$ & $M, F$ & Random & Quantitative & Questionnaire & Question & 14 & 87.5 \\
\hline \multirow{6}{*}{ Older adults } & $\begin{array}{c}\text { Nascimento } \\
\text { et al. }{ }^{11}\end{array}$ & 2008 & Rio Claro & $\mathrm{SP}$ & 129 & $\geq 60$ & $M, F$ & Random & Quantitative & Questionnaire & Hirayama & 6 & 37.5 \\
\hline & Gobbi et al. ${ }^{34}$ & 2008 & Rio Claro & $\mathrm{SP}$ & 30 & $\geq 65$ & $M, F$ & Intentional & Quantitative & Questionnaire & Hirayama & 7 & 43.8 \\
\hline & Brazao et al. ${ }^{35}$ & 2009 & $\mathrm{NI}$ & $S P$ & 79 & $60-88$ & $M, F$ & Random & Quantitative & Questionnaire & Hirayama & 8 & 50.0 \\
\hline & Cassou et al. ${ }^{36}$ & 2011 & Curitiba & $\mathrm{PR}$ & 25 & $>60$ & $\mathrm{~F}$ & Intentional & Quantitative & Focus group & Focus group & 9 & 56.2 \\
\hline & Gobbi et al. ${ }^{37}$ & 2012 & Rio Claro & $\mathrm{SP}$ & 359 & $60-\geq 88$ & $M, F$ & Random & Quantitative & Questionnaire & Hirayama & 12 & 75,0 \\
\hline & Lopes et al. ${ }^{38}$ & 2016 & Florianópolis & SC & 69 & $\geq 80$ & $\mathrm{~F}$ & Intentional & Qualitative & Focus group & Focus group & 12 & 75.0 \\
\hline
\end{tabular}

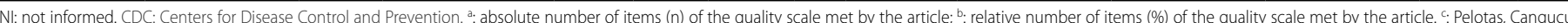
Piratini, São Lourenço do Sul, and Cerrito. d: Santo André and São Bento do Sapucaí. e: Program Agita São Paulo Questionnaire.

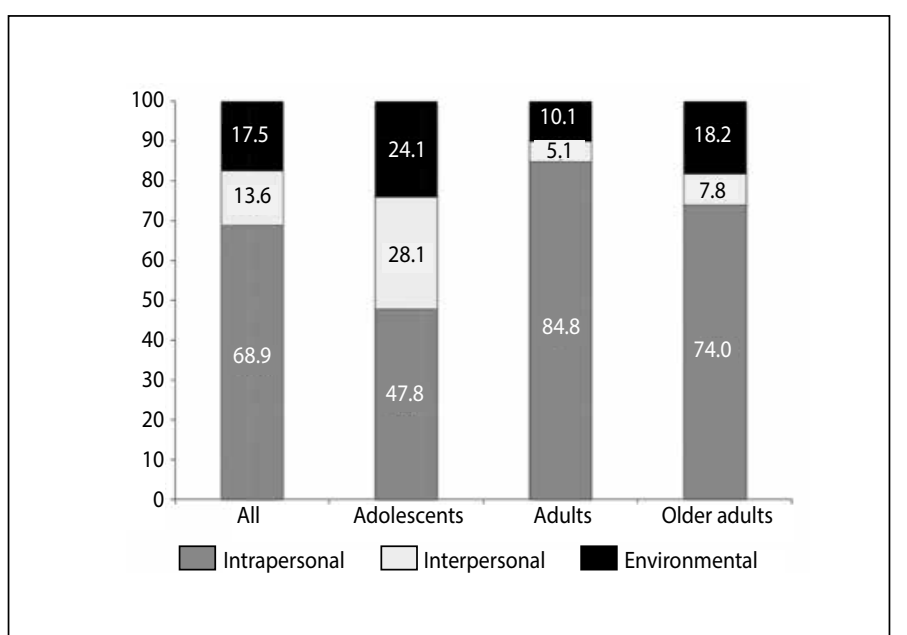

Figure 2. Perceived barriers to physical activity at each level of the socioecological model according to age group in the Brazilian population (2016).

\section{Main types of barriers to physical activity in the Brazilian population}

Figure 4 shows the proportion of the main barriers to PA according to sex, age group, and socioecological determinant. The proportion of barriers related to the lack of motivation (lack of motivation and laziness), lack of social support (lack of companionship and lack of support from family and friends), and climate and access factors (inappropriate climate and lack of places and facilities) was higher in adolescents. Interestingly, girls more frequently reported barriers related to the lack of motivation

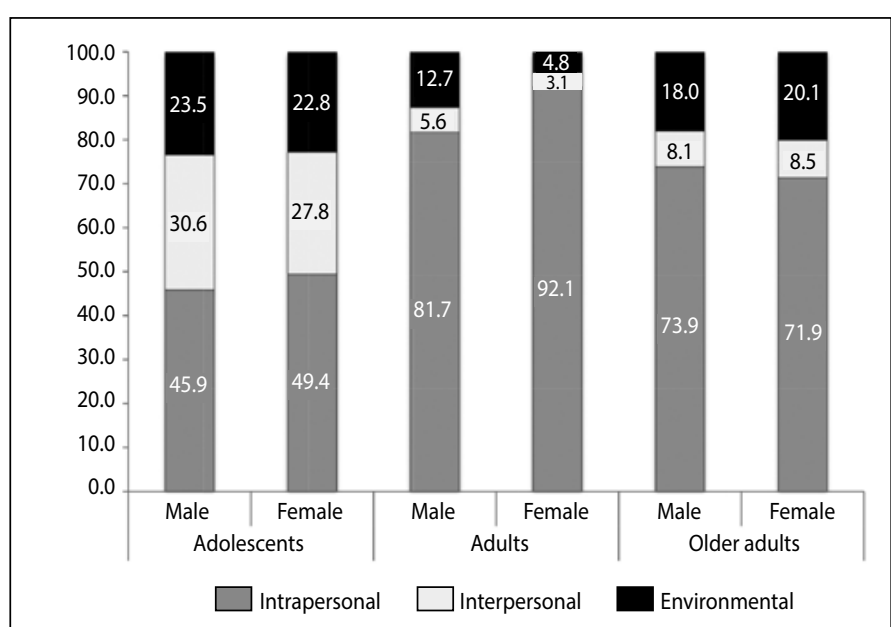

Figure 3. Perceived barriers to physical activity at each level of the socioecological mode according to age group and sex in the Brazilian population (2016).

(not liking to exercise, lack of motivation, laziness, and preference for other leisure-time activities) than boys.

In adults, women reported the lack of motivation, lack of companionship and lack of financial resources as the main barriers, while men more frequently reported the lack of time and social and structural aspects (lack of safety, lack of places and equipment for PA). Among older adults, the lack of motivation as the main barrier to PA in men calls attention. In older women, the barriers were related to physical limitations, presence of diseases, lack of companionship, and lack of safety (Figure 4). 


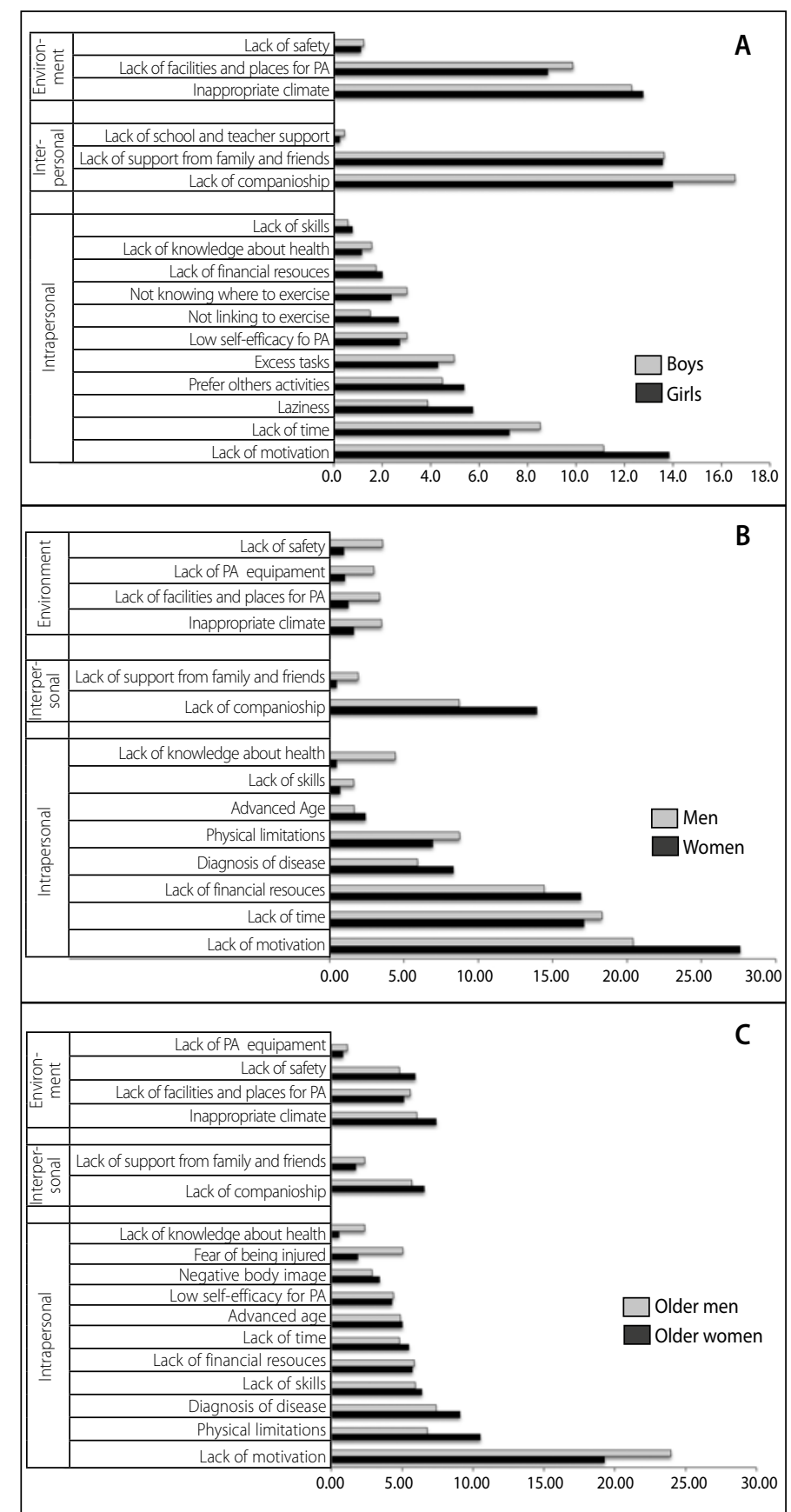

Figure 4. Relative frequency of perceived barriers to physical activity according to age group. A) Adolescents: nine studies that used gender-stratified analysis were included (absolute frequency of barriers $=16,832$ barriers cited by girls and 11,308 by boys). B) Adults: five studies that used gender-stratified analysis were included (absolute frequency of barriers $=5,443$ barriers cited by women and 4,662 by men). C) Older adults: three studies that used gender-stratified analysis were included (absolute frequency of barriers $=2,083$ barriers cited by women and 1,153 by men).

\section{DISCUSSION}

The results of this systematic review demonstrate growing interest in the study of barriers to PA, but few studies have investigated these barriers in the Brazilian population, especially older adults, children and populations from the Midwest and Northern regions of the country. Most of the evidence was obtained with standardized scales/questionnaires, but little information is available about the quality of the measure and few studies used qualitative methods. Regarding the quality of the studies, slightly more than half (56.0\%) met at least $70 \%$ of the items of the scale used ${ }^{18}$. This percentage was $54.5 \%$ in adolescents, $75.0 \%$ in adults, and $33.6 \%$ in studies involving older adults, demonstrating the need to improve the quality of research, especially that involving children and the elderly. Another important finding was the higher proportion of barriers to PA at the intrapersonal level, a fact observed in all age groups. However, differences in the proportions were found between groups, with a higher proportion of intrapersonal barriers in adult women compared to adult men.

There is a lack of evidence for barriers to PA from major regions of the country, with no studies being available for the Northern and Midwest regions. Research in these regions would be important considering that their population accounts for approximately $15 \%$ of the national population and that the rates of insufficient levels of PA are considerable ${ }^{39}$. This paucity of evidence may be related at least in part to a poor research capacity, which is confirmed by the small number of postgraduate programs in these regions ${ }^{40}$. In this respect, increasing the attention of already established programs and research groups to this topic as well as the expansion of programs in these regions can contribute to reduce this knowledge gap. Furthermore, most studies used quantitative methods to investigate barriers to PA. Although these studies are important to establish the magnitude and distribution of PA barriers, investment in qualitative studies is necessary to unravel aspects not included in the questionnaires used and to determine the significance of these aspects for each population group. Almost all quantitative studies identified in the literature use questionnaires that contain items adapted from instruments developed in other countries. Despite adequate reliability, these instruments may be less relevant to the context of the country ${ }^{28}$. Finally, some quantitative studies use questionnaires containing the original items, but do not report information about the quality of the measures ${ }^{11,19}$. Therefore, qualitative studies may also identify new items to be included in questionnaires on barriers to PA.

A predominance of perceived intrapersonal barriers to PA was observed, regardless of age group (Figures 2 and 3). This finding agrees with other studies demonstrating that the most frequently reported barriers to PA are associated with individual factors ${ }^{37}$. This result is important because it suggests that strategies designed to promote PA need to consider individual aspects such as preferences and the level of complexity of the activities. For example, by performing preferred and easier activities, individuals increase their perception of competence and motivation ${ }^{41}$, with positive effects on adherence to PA programs. In addition, PA is a behavior that is susceptible to the interaction of personal, social, environmental and socio-political factors ${ }^{5}$, and changes in any of these factors can therefore positively influence the others. Thus, a broader approach to PA barriers is required since individual variables are insufficient to understand the complexity of this behavior ${ }^{17}$.

The main barriers identified among adolescents were the lack of companionship, lack of social support from family and friends, inadequate climate, and limited access to places for PA (Figure 4A). Social support and encouragement of PA are strongly associated with higher levels of $\mathrm{PA}^{42}$. Within this context, promoting activities and facilities that increase social interaction, such as skating rinks and sports courts, seems to be an important alternative to increase PA levels in this population group. On the other hand, family support, either financial/resources or emotional, can be important to provide access to activities and places and to increase confidence and motivation for PA. The barriers related to social support were similar for boys and girls, but their proportion was higher among girls. This finding may explain in part the decline in PA levels observed among girls after adolescence and suggests the need to pay greater attention to this subgroup ${ }^{42}$. No studies involving children were found, which demonstrates a clear lack of knowledge on the topic. Early childhood is fundamental for positive reinforcement of habits and behaviors. In addition, available evidence suggests low levels of PA in children ${ }^{43}$. Taken together, these findings highlight the need to 
give priority to studies investigating barriers to PA in this group. However, given the complexity of measuring barriers in children, it is important to conduct exploratory studies using innovative and mixed methods, such as combining parent reporting and direct observation. This complexity may explain to some extent the lack of studies found in this review.

A large number of barriers were observed in adults, with the main barriers being the lack of motivation and lack of time (Figure 4B). Women more frequently reported intrapersonal barriers than men. These results corroborate the findings of international studies ${ }^{4,44}$. The lack of motivation has been evaluated as a possible barrier associated with a decrease in the level of PA. Bowles et al ${ }^{45}$ demonstrated a significant association between this barrier and the level of PA, while Genkinger et al $^{46}$ found no significant association. Thus, further investigation is needed. In an attempt to engage people in health promotion initiatives and to encourage an active lifestyle or behavior change, different alternatives should be designed to reach the maximum number of individuals possible, always considering the particularity of each group with regard to barriers or facilitators, the applicability and effectiveness of the intervention, and cultural aspects of the place ${ }^{12}$. With respect to lack of time, a recent review shows that this variable is linked to an excessive number of family commitments and household duties and excess demands and workload, and can actually be an important barrier ${ }^{47,48}$. Within this context, it is important to understand that lack of time is not simply an excuse not to perform PA. Apparently, most people have difficulties organizing their activities within the time available. Thus, strategies to promote PA should increase the opportunities for PA in all contexts (home, work, transportation, and leisure) to facilitate the inclusion of this behavior in daily activities.

In older adults, the main barriers reported were the lack of motivation, diagnosis of disease, or physical limitation. Lack of motivation has also been reported as an important barrier for older adults in the international literature ${ }^{49,50}$. An important finding of the present study was that, in contrast to the adolescent and adult groups, in older adults, the lack of motivation barrier was more frequently reported by men. The development of strategies for older men to remain motivated during the transition from adulthood to old age may be an important focus as this motivation seems to decrease over the years. In addition, the presence of diseases and limitations that were frequently reported as barriers to PA are related to the aging process itself. Elderly patients with musculoskeletal disorders and individuals with existing diseases have low levels of PA ${ }^{51}$. However, it should be emphasized that participation in PA programs is associated with improvements in health status, increased social contact and disease prevention in older adults ${ }^{52}$, which may become a facilitating factor and enable individuals to overcome these barriers. The existence of diseases does not necessarily prevent the participation in PA programs, while participation can preserve the autonomy of older adults and improve their quality of life ${ }^{49}$.

One limitation of this study is the fact that it did not select studies published in non-indexed journals of the databases. Thus, it is possible that studies involving the populations analyzed were not included. However, the databases searched here are those most used in studies on the topic, in addition to requiring a blind peer-review process for the evaluation of articles, thus establishing minimum scientific quality criteria.

In conclusion, there is growing interest in the study of barriers to PA, but few studies have investigated these barriers in the Brazilian population, especially older adults, children and populations from the Midwest and Northern regions of the country. Intrapersonal barriers continue to be the barriers most frequently reported by the Brazilian population and include the lack of companionship, lack of social support from family and friends, inadequate climate and limited access to places for PA in adolescents; lack of motivation and lack of time in adults, and lack of motivation and diagnosis of disease or physical limitation in older adults. Physical activity promotion programs must take into account the different barriers to PA since they were found to be specific for each age group.

All authors declare no potential conflict of interest related to this article.

AUTHORS' CONTRIBUTIONS: Each author made significant individual contributions to this manuscript. CRR (0000-0002-9647-3448)* participated in the initial concept of the study and contributed to the writing and critical review of the text. EMC (0000-0003-2127-2606)* was responsible for bibliographical research, evaluation, selection of the articles, data collection and analysis, and writing of the manuscript. PA (0000-0002-9414-5870)* participated in the bibliographical research, selection of the articles, data collection, evaluation, and writing of the manuscript. MRL (0000-0002-2680-4686)* participated in the discussion and critical review of the article. RSR (0000-0002-9872-9865)* participated in the concept and conducted the discussion and critical review of the article. ${ }^{*} \mathrm{ORCID}$ (Open Researcher and Contributor ID).

\section{REFERENCE}

1. Salmon J, Owen N, Crawford D, Bauman A, Sallis JF. Physical activity and sedentary behavior: a population-based study of barriers, enjoyment, and preference. Health psychology 2003;22(2):178.

2. Sallis JF, Cervero RB, Ascher W, Henderson KA, Kraft MK, Kerr J. An ecological approach to creating active living communities. Annu. Rev. Public Health 2006;27:297-322.

3. Sallis JF, Prochaska JJ, Taylor WC. A review of correlates of physical activity of children and adolescents. Med Sci Sports Exerc 2000;32(5):963-975

4. Trost SG, Owen N, Bauman AE, Sallis JF, Brown W. Correlates of adults' participation in physical activity: review and update. Med Sci Sports Exerc 2002;34(12):1996-2001

5. Bauman AE, Reis RS, Sallis JF, Wells JC, Loos RJF, Martin BW. Correlates of physical activity: why are some people physically active and others not? The Lancet 2012;380(9838):258-271.

6. Dambros DD, Lopes LFD, Santos DLd. Barreiras percebidas e hábitos de atividade física de adolescentes escolares de uma cidade do sul do Brasil. Rev. bras. cineantropom. desempenho hum 2011;13(6):422-428.

7. Santos MS, Hino AAF, Reis RS, Rodriguez-Añez CR. Prevalência de barreiras para a prática de atividade física em adolescentes. Rev Bras Epidemiol 2010;13(1):94-104.

8. Reis RS, Silva DAS, Petroski EL. Barreiras e facilitadores de atividades físicas em freqüentadores de parques públicos. Motriz 2009;15(2):219-227.

9. Camargo E, Fermino R, Rodriguez-Añez C, Reis R. Barriers and facilitators to bicycle use for transport and leisure among adults. Revista Brasileira de Atividade FÍsica \& saúde 2014;19(2):256-265.

10. Cassou ACN, Fermino RC, Santos MS, Rodriguez-Añez CR, Reis RS. Barreiras para a atividade física em idosos: Uma análise por grupos focais. R. da Educação Física/UEM 2008;19(3):353-360.
11. Nascimento CMC, Gobbi S, Hirayama MS, Brazão MC. Nível de atividade física e as principais barreiras percebidas por idosos de Rio Claro. Journal of Physical Education 2008;19(1):109-118.

12. Joseph RP, Ainsworth BE, Keller C, Dodgson JE. Barriers to physical activity among African American women: an integrative review of the literature. Women \& health 2015;55(6):679-699.

13. Diez Roux AV, Mair C. Neighborhoods and health. Ann N Y Acad Sci 2010;1186:125-145.

14. Sallis JF, Floyd MF, Rodriguez DA, Saelens BE. Role of Built Environments in Physical Activity, Obesity, and Cardiovascular Disease. Journal of the American Heart Association 2012;125(2012):729-737.

15. Reis RS, Salvo D, Ogilvie D, Lambert EV, Goenka S, Brownson RC, et al. Scaling up physical activity interventions worldwide: stepping up to larger and smarter approaches to get people moving. The Lancet 2016;388(10051):1337-1348.

16. Galvão TF, Pansani TdSA, Harrad D. Principais itens para relatar revisões sistemáticas e meta-análises: a recomendação PRISMA. Epidemiologia e Serviços de Saúde 2015;24:335-342.

17. Sallis JF, Floyd MF, Rodríguez DA, Saelens BE. Role of built environments in physical activity, obesity, and cardiovascular disease. Circulation 2012;125(5):729-737.

18. Downs SH, Black N. The feasibility of creating a checklist for the assessment of the methodological quality both of randomised and non-randomised studies of health care interventions. Journal of Epidemiology and Community Health 1998;52(6):377-384.

19. Teixeira CP, MartinoffT, Ferreira MT. Barreiras para a prática de atividade física entre adolescentes. Revista de Atenção à Saúde 2010;2(4):18-22.

20. Ceschini FL, Figueira Jr. A. Barreiras e determinantes para a prática de atividade física em adolescentes. $\mathrm{R}$ bras Ci e Mov 2007;15(1):29-36. 
21. Junior AF, Ferreira MBR, Ceschini FL, Alvares LD. Percepção das barreiras e prática de atividade física em adolescentes residentes em regiões metropolitana e interiorana do Estado de São Paulo. Rev. bras. ciênc. mov 2008;16(3):1-19.

22. Santos MS, Fermino RC, Reis RS, Cassou AC, Rodriquez-Añez C. Barreiras para a prática de atividade física em adolescentes. Um estudo por grupos focais. Rev Bras Cineantrop Desempenho Hum 2010;12(3):137-143.

23. Copetti J, Neutzling MB, da Silva MC. Barreiras para prática de atividades físicas em adolescentes de uma cidade do sul do Brasil. Revista Brasileira de Atividade Física \& Saúde 2012;15(2):88-94.

24. Silva S, Diego A, Menezes AS, de Almeida-Gomes M, Ferreira de Sousa T. Estágios de mudanças de comportamento para atividade física em estudantes de uma cidade do Brasil. Revista de Salud Pública 2010;12(4):623-634

25. Silva KS, Vasques DG, Martins CdO, Williams LA, Lopes AS. Active commuting: prevalence, barriers, and associated variables. J Phys Act Health 2011;8(6):750.

26. de Andrade Müller W, da Silva MC. Barreiras à prática de atividades físicas de adolescentes escolares da zona rural do sul do Rio Grande do Sul. Revista Brasileira de Atividade Física \& Saúde 2013;18(3):344-353.

27. Dias $D F$, Loch MR, Ronque ERV. Barreiras percebidas para à prática de atividades físicas no lazer e fatores associados em adolescentes. Revista Ciências \& Saúde Coletiva 2015;20(11):3339-3350.

28. Reichert FF, Barros AJ, Domingues MR, Hallal PC. The role of perceived personal barriers to engagement in leisure-time physical activity. Am J Public Health 2007;97(3):515-519.

29. Silva DAS, Petroski EL, Reis RS. Barreiras e facilitadores de atividades física em frequentadores de parques públicos. Motriz 2009;15(2):219-227.

30. Nogueira JAD, de Sousa AFM. Barreiras percebidas e etapas de mudança de comportamento relacionadas prática de atividade física em professores de escolas públicas. Revista Brasileira de Ciência e Movimento 2012;20(1):65-70.

31. Rigoni PAG, do Nascimento Junior JRA, de Souza Costa GNF, Vieira LF. Estágios de mudança de comportamento e percepção de barreiras para a prática de atividade física em universitários do curso de Educação Física. Revista Brasileira de Atividade Física \& Saúde 2012;17(2):87-92.

32. de Jesus GM, de Jesus ÉFA. Nível de atividade física e barreiras percebidas para a prática de atividades físicas entre policiais militares. Revista Brasileira de Ciências do Esporte 2011;34(2):433-448.

33. Silva K, Del Duca G, Garcia L, Silva J, Bertuol C, Oliveira E, et al. Barriers associated with frequency of leisure time physical activity among Brazilian adults of different income strata. Scandinavian journal of medicine \& science in sports 2016;26(2):206-213.

34. Gobbi S, Caritá LP, Hirayama MS, Quadros Junior ACd, Santos RF, Gobbi LTB. Comportamento e barreiras Psicologia: teoria e pesquisa 2008;24(4):451-458

35. Brazão MC, Hirayama MS, Gobbi S, Nascimento CMC, Roseguini AZ. Estágio de mudança de comportamento e barreiras percebidas prática de atividade física em idosos residentes em uma cidade de médio porte do Brasil. Motriz rev. educ. física 2009;15(4):759-767.

36. Cassou A, Fermino R, Reis R, Rodrigues Anez C, Santos M, Domingues M. Barriers to physical activity among brazilian elderly women from different socioeconomic status. A focus-group study. J Phys Activ Health 2011:8(1):126-132.
37. Gobbi So, Sebastiv£o E, Papini CB, Nakamura PM, Valdanha Netto Ar, Gobbi LTB, et al. Physical inactivity and related barriers: a study in a community dwelling of older brazilians. Journal of Aging Research 2012;2012.

38. Lopes MA, de Rosso Krug R, Bonetti A, Mazo GZ. Barreiras que influenciaram a não adoção de atividade física por longevas. Revista Brasileira de Ciência do Esporte 2016;38(1):76-83.

39. VIGITEL. Ministério da Saúde B. VIGITEL 2013. Vigilância de fatores de risco e proteção para doenças crônicas por inquérito telefônico. Secretaria de Vigilância em Saúde. Departamento de Vigilância de Doenças e Agravos não Transmissíveis e Promoção de Saúde. Brasília 2013.

40. Estratégicos CCdGeE. Mestres e doutores 2015. Estudo da demografia da base técnino-científica brasileira. Brasília, DF: 2016. 348p. 2016.

41. Bielemann RM, Xavier MO, Gigante DP. Preferência por comportamentos favoráveis à prática de atividade física e nível de atividade física de crianças de uma cidade do sul do Brasil. Ciência \& Saúde Coletiva 2014;19(7):2287-2296.

42. Farias Júnior JCd, Reis RS, Hallal PC. Physical activity, psychosocial and perceived environmental factors in adolescents from Northeast Brazil. Cadernos de Saúde Pública 2014;30(5):941-951.

43. Mélo EN, Barros M, Hardman C, Siqueira M, Wanderley J $\sqrt{ }$ nior R, Oliveira E. Associação entre o ambiente da escola de educação infantil e o nível de atividade física de crianças pré-escolares. Revista Brasileira de Atividade Física e Saúde 2013;18(1):53-62.

44. Bellows-Riecken KH, Rhodes RE. A birth of inactivity? A review of physical activity and parenthood Preventive medicine 2008:46(2):99-110.

45. Bowles HR, Morrow Jr JR, Leonard BL, Hawkins M, Couzelis PM. The association between physical activity behavior and commonly reported barriers in a worksite population. Research Quarterly for Exercise and Sport 2002;73(4):464-470

46. Genkinger JM, Jehn ML, Sapun M, Mabry I, Young DR. Does weight status influence perceptions of physical activity barriers among African-American women? Ethnicity and Disease 2006;16(1):78.

47. Kelly S, Martin S, Kuhn I, Cowan A, Brayne C, Lafortune L. Barriers and facilitators to the uptake and maintenance of healthy behaviours by people at mid-life: a rapid systematic review. PLoS One 2016;11(1):e0145074.

48. Fransson El, Heikkil/ $\S$ K, Nyberg ST, Zins M, Westerlund H, Westerholm P, et al. Job strain as a risk facto for leisure-time physical inactivity: an individual-participant meta-analysis of up to 170,000 men and women The IPD-Work Consortium. American Journal of Epidemiology 2012:kws336.

49. Moschny A, Platen P, KlaaVüen-Mielke R, Trampisch U, Hinrichs T. Barriers to physical activity in older adults in Germany: a cross-sectional study. International Journal of Behavioral Nutrition and Physical Activity 2011;8(1):1

50. Crombie IK, Irvine L, Williams B, McGinnis AR, Slane PW, Alder EM, et al. Why older people do not participate in leisure time physical activity: a survey of activity levels, beliefs and deterrents. Age Ageing 2004;33(3):287-292

51. Picorelli AMAo, Pereira LSMx, Pereira DS, Fel $\sqrt[\neq c i o]{ } D$, Sherrington C. Adherence to exercise program for older people is influenced by program characteristics and personal factors: a systematic review. Journal of physiotherapy 2014;60(3):151-156.

52. Gomes KV, Zazí DC. Motivos de adesão à prática de atividade física em idosas. Revista Brasileira de Atividade Física \& Saúde 2012:14(2):132-138. 